\title{
MikroRNA'lar ve çiftlik hayvanlarında kullanım alanları
}

\author{
Mücahit KAHRAMAN ${ }^{1, a}$, Banu YÜCEER ÖZKUL ${ }^{2, b, *}$ \\ ${ }^{1}$ Harran Üniversitesi, Veteriner Fakültesi, Zootekni Anabilim Dall, Şanlıurfa, Türkiye \\ ${ }^{2}$ Ankara Üniversitesi, Veteriner Fakültesi, Zootekni Anabilim Dall, Ankara, Türkiye. \\ ORCID: 0000-0002-7757-2483 ; $0000-0002-7036-6230^{b}$
}

\author{
MAKALE BILGISI/ \\ Geliş / Received: \\ 15 Ocak 20 \\ 15 January 20 \\ Kabul/Accepted: \\ 21 Nisan 20 \\ 21 April 20 \\ Anahtar Sözcükler: \\ Biyomarker \\ Çiftlik Hayvanları \\ MikroRNA \\ Seleksiyon \\ SNP
}

ARTICLE INFORMATION:

Keywords:

Biomarker

Livestock

MikroRNA

Selection

SNP
ÖZET:

Son yıllarda genetik alanında meydana gelen ilerlemeler, hayvan yetiştiriciliğinde farklı seleksiyon yaklaşımlarını ortaya çıkartmıştır. Yaklaşık olarak 22 nükleotidden oluşan ve mikroRNA olarak adlandırılan moleküllerin, gen ekspresyonlarının $\% 25$ 'ini etkilediği düşünülmektedir. Ayrıca miRNA'ları kodlayan genlerdeki SNP (Single Nucleotide Polymorphism) noktalarının çiftlik hayvanlarında ekonomik öneme sahip verim özellikleriyle ilişkili oldukları bildirilmektedir. Son yıllarda yapılan çalışmalarda miRNA'ların ekspresyon ve fonksiyonlarının araştırılması hususunda ilerleme sağlanmış olup verim özelliklerinin belirlenmesinde miRNA'ların çiftlik hayvanlarında biyomarker olarak kullanımı gündeme gelmiştir. Bu derlemede, miRNA'lar ve çiftlik hayvanlarında kulanım alanları hakkında bilgi verilmiştir.

\section{MikroRNAs and mikroRNAs using areas in livestock}

ABSTRACT:

In recent years, advances in genetics have led to different selection approaches in animal husbandry. The molecules composed of approximately 22 nucleotides, called microRNA, that can effect the expression of $25 \%$ of the genes. On the other hand, to be expressed to some correlations between economically important feature and miRNA coding gene SNPs. In recent studies, investigation of the expression and function of miRNAs have been made progress. Therefore, became a current issue to the using of miRNAs as biomarker for detection of production traits in livestock species. In this review have been informed about miRNAs and using area of miRNA in livestock.

How to cite this article: Kahraman M, Özkul BY: MikroRNA'lar ve çiftlik hayvanlarında kullanım alanları. Veteriner Hekimler Dernegi Dergisi, 91(2): 193-202, 2020, DOI: 10.33188/vetheder.674850

* Sorumlu Yazar e-posta adresi / Corresponding Author e-mail address: yuceerbanu@ hotmail.com 


\section{Giriş}

Çiftlik hayvanları kompleks yapılı canlılardır ve hala bilinmeyen tarafları bulunmaktadır. Ancak, başarılı bir yetiştiricilik yapılabilmesi için hayvanların biyolojik yapılarının iyi bilinmesi gerekmektedir (2). Dolayısıyla, çiftlik hayvanlarının gelişiminde etkili olan faktörlerin anlaşılması ve bu faktörlere göre seleksiyon programlarının oluşturulmasının önemi artmaktadır (47). Bu amaçla ekonomik yönden önemli verim özelliklerini etkileyen genetik faktörlerin tanımlanması hususunda genom boyu taramalar yapılmaktadır (12). Bu çalışmalar sayesinde; 1993 yılında miRNA (mikroRNA)'lar keşfedilmiştir. Yaklaşık olarak 22 nükleotidden oluşan bu küçük RNA moleküllerinin (6), gen ekspresyonlarının (ifadelerinin) \%25'ini etkilediği düşünülmektedir (59). Ayrıca miRNA'ları kodlayan genlerdeki SNP (Single Nucleotide Polymorphism) noktalarının çiftlik hayvanlarında ekonomik öneme sahip verim özellikleriyle ilişkili oldukları bildirilmektedir (34). Bu amaçla miRNA'ların ekspresyon ve fonksiyonlarının araştırılması hususunda ilerleme sağlanmış olup (55) verim özelliklerinin belirlenmesinde miRNA'ların çiftlik hayvanlarında biyomarker olarak kullanımı gündeme gelmiştir (25).

\section{RNA Molekülü ve Fonksiyonları}

Canlılarda genetik materyal DNA (Deoksiribonükleik Asit) olup, DNA'daki bilginin RNA (Ribo Nükleik Asit)'ya transkripsiyonu (yazılımı) yapıldıktan sonra protein sentezi gerçekleşmektedir. DNA'nın büyük bir bölümü, RNA'ya kodlanmasına rağmen bu genomun çok küçük bir miktarı (yaklaşı \%1.5) fonksiyonel protein sentezinde kullanılmaktadır. Proteine çevrilmeyen ve kodlanmayan RNA (ncRNA/non-coding RNA) olarak ifade edilen kısımların, yakın zamana kadar çok az öneme sahip olduğu düşünülmüştür (61). Ayrıca gen arama çalışmaları geleneksel olarak protein kodlayan dizilere yönelik olduğundan, birçok gen göz ardı edilmiştir. Ancak son y1llarda yapılan araştırmalarda kodlanmayan RNA'ların, gen ifadelerinin düzenlenmesi gibi pek çok önemli biyolojik olayda rol oynayan çok sayıda çeşidinin bulunduğu ortaya konulmuştur (11). Organizmada hangi genlerin aktif olduğunu ve bu genlerin nasıl etkin olduklarını kontrol eden bir sistem bulunmakta ve RNA interference (RNAi) sistemi olarak adlandırılmaktadır. RNAi'nin 3 tipi vardır. Endojen kaynaklı miRNA (miRNA/miR), eksojen small interfering RNA (siRNA) ve eşey hücrelerindeki piwi-etkileşimli RNA (piRNA)'dır. Bu RNA'ların post-transkripsiyonel gen regülasyonunda önemli görevleri vardır. Genlerin direk ürünleri olan RNA'lar bu RNA'lara bağlanarak aktivitelerini azaltabilmekte (mRNA translasyonunu engelleyebilir) veya arttırabilmektedirler. RNAi'ler kodlanmayan RNA'lardandır ve DNA'dan transkripsiyonu yapılan ama proteine translasyonu (çevirisi) yapılmayan genler tarafından kodlanmaktadırlar (30).

\section{MikroRNA'lar}

MiRNA'lar, genom üzerinde protein kodlayan ekzon bölgeleri ile protein kodlamayan intron bölgelerindeki RNA genlerinden transkripsiyonu sağlanan, fakat proteine translasyonu gerçekleşmeyen fonksiyonel RNA molekülleridir. MiRNA, fonksiyon olarak gen ekspresyonunun düzenlenmesinde rol oynayan, yaklaşı olarak 18-24 nükleotid uzunluğunda tek iplikçikli bir RNA molekülüdür (49). Bir veya birden fazla hedef geni baskılayarak gelişim, farklılaşma, çoğalma, hücre ölümü gibi süreçlerde rol oynarlar (54).

\section{MikroRNA'ların Tarihçesi}

MiRNA'ların araştırıldığı ilk çalışma Lee ve ark., (1993) tarafından, bir yuvarlak solucan olan Caenorhabditis elegans üzerinde yapılmıştır. Bu nematod, gen içeriği bakımından taranmıştır ve Lin-4 olarak adlandırılan genin hiçbir proteini kodlamamasına karşın hedef genin ifadesini azalttı̆̆ gözlemlenmiştir. Lin-4'ün, Lin-14 mRNA (mesajc1 RNA)'nın 3'UTR (untranslated region)'sinde (60) tamamlayıcı olan 22 ve 61 nükleotidlik (32) iki transkripti bulunmaktadır. Lin-14 mRNA, farklı türlerin embriyosunda ve C. elegans'ın 1. larva aşamasında mevcut olan Lin-14 proteinini kodlar (16, 60). Lin-14, RNA-RNA interaksiyonu vasitasiyla Lin-4 ile baskılanması sebebiyle Lin-14 protein 
seviyesinde azalışa neden olur ancak, Lin-14 mRNA seviyesi sabit kalır (60). Bu veriler, Lin-4'ün, Lin-14'ün kodlama yapmayan bölgesine eşlenmesi ile Lin-14'ün baskılanması sonucunda 1. larva aşamasından 2. larva aşamasına geçişe neden olan bir durumu ortaya çıkarmıştır $(6,16,32,60)$.

Reinhart ve ark., (2000), yine aynı nematodda 22 nükleotid uzunluğunda, Let-7 olarak adlandırılan ve canlının gelişimini düzenleyen farklı bir RNA keşfetmişlerdir. Daha sonraki yıllarda Lin-4 ve Let-7'ye benzer birçok küçük RNA molekülü tespit edilmiştir ve miRNA'lar olarak adlandırılmıştır $(31,45)$.

MiRNA'ların birçok canlı türünde, gelişim sırasında embriyogenezde, farklılaşmada, gelişimin düzenlenmesinde, organogenezde, büyümenin kontrolünde, proliferasyonda, programlanmış hücre ölümünde, immun yanıt ve lenfosit fonksiyonunda rol oynadıklarını (6), dolayısıyla da kök hücre, embriyo, beyin, kalp, karaciğer gibi tüm hayvansal dokuların normal gelişiminden sorumlu oldukları bildirilmektedir (30).

\section{5. Çiftlik hayvanlarında mikroRNA'lar}

MiRNA araştırmalarının çoğu insanlarda kanser hastalığının mekanizmasını aydınlatmak üzerine yoğunlaşmıştır. Çiftlik hayvanlarında da miRNA profilleme çalışmaları bulunmakta olup, doku ve organ gelişiminde, immun yanıtın şekillenmesi ve metabolik olaylarda miRNA gen ifadelerinin etkili olduğu bildirilmektedir. Ayrıca, miRNA genlerinde bulunan SNP noktalarının hayvanlar arasındaki fenotipik farklılıklar, verim özellikleri ve hastalıklara yatkınlıkla ilişkili olduğunu gösteren çalışmalar da bulunmaktadır (25).

\subsection{Sığırlarda mikroRNA'lar}

Sığırlarda miRNA'lar ile ilgili çalışmalar yağ doku, iskelet kası, oosit gelişimi ve erken embriyonik gelişmeler ile süt verimi ve mastitis üzerine yoğunlaşmaktadır (59).

Sığırlarda miRNA'ların yağ doku üzerine etkilerinin araştırıldığı bir çalışmada, üç farklı melez sığır genotipi; Şarole X Maine Anjou (CHAM), Şarole X Kırmızı Angus (CHAR) ve Hereford X Aberdeen Angus (HEAN) sırt yağı kalınlığına göre (düşük ve yüksek) 6 gruba (Şekil 1) ayrılarak incelenmiştir. Bu 3 grup arasında 42 miRNA'da gözlenen ekspresyon farklılıklarının anlamlı olduğu bildirilmiştir. Bu miRNA'lardan 18'inin ifade seviyesi ile sırt yağı kalınlığı arasında korelasyonlar ortaya konulmuştur. Bu korelasyonlardan en önemlisi fazla sırt yağı kalınlığına sebep olan miR$378(\mathrm{r}=0.72 \mathrm{p}<0.0001$ )'dir. Bu araştırma, etçi sığırlarda yağ dokusu oluşumu üzerine miRNA'ların etkili olabileceğini göstermektedir (26). MiR-143 ekspresyonu, kas içi preadiposit oluşumunu düzenlemektedir dolayısıyla bu miRNA sığırlarda intramusküler yağ oluşumu üzerine etkili olmaktadır (35). MiR-143 haricinde, yağ doku oluşumu üzerinde etkili olan 8 miRNA (miR-19a, -92a, -92b, -101, -103, -106, -142-5p ve -296) daha bulunmaktadır. Bu miRNA'ların yüksek yağ oranı içeren rasyonlarla beslemeye daha iyi cevap verdiği bildirilmektedir (48).

MiR-1 ve miR-206, kas hücresi farklılaşmasında önemli rol oynayan spesifik iki miRNA'dır (52). Çift kaslaşma özelliğine sahip Piedmontese ırkı sığırlarda bu iki miRNA ekspresyonu incelenmiş ve miRNA-206'nın daha yüksek düzeyde ekspresyon seviyesi gösterdiği bildirilmiştir. Bu durum miR-206'nın Piedmontese sığırlarında musküler hipertrofiye sebep olabileceğini düşündürmektedir (7). Fare embriyosu üzerinde yapılan bir çalışmada, miR181b'nin miyoblastların farklılaşmasında görev aldığı bildirilmiştir (43). Angus sığır ırkında yapılan bir çalışmada ise, miR-181b'nin bu sığır ırkında miyogenezde etkili olduğu gösterilmiştir (65).

Sığırlarda, miRNA'ların üreme sistemi üzerinde de etkili olduğunu gösteren çalışmalar bulunmaktadır. MiR205, -150, -122, -96, -146a ve -146b-5p'nin ositlerde ekspresyon miktarı oldukça fazladır. Bu miRNA'ların ekspresyonunun, olgunlaşmayı (maturasyon) takiben 22 saat içerisinde hızla düştügü bildirilmiştir. Bu durum ositlerin olgunlaşması sırasında miRNA'ların etkili olabileceğini düşündürmektedir (1). Sığırlarda ogenezin son safhasında Kümülüs Osit Kompleksi üzerine miRNA ekspesyonlarının incelendiği bir çalışmada, miR-106a'nın sığır oositlerindeki ekspresyonu Kümülüs Osit Kompleksine göre oldukça fazla iken miR-106a'nın hedef geni olan WEE1'in ekspresyonunun ositlerde daha az olduğu bildirilmiştir (41). Yine benzer şekilde miR-196a ve miR-181a'nın sirasiyla NOBOX (Newborn Ovary Homeobox Gene) ve NPM2 (Nucleoplasmin 2)'yi etkileyerek folikülogenezi etkilediği bildirilmektedir $(38,53)$. Sığır embriyosunda bulunan miR-21 ve miR-130a' nın ekspresyonu 1 hücreli 
safhadan 8 hücreli safhaya kadar artmaktadır. Bu miRNA'ların embriyonik gelişim üzerinde etkili olduğu düşünülmektedir (42).

Süt sığırlarında süt üretimi ve mastitis üzerinde etkili olan aday genler ve markerlerin belirlendiği bir veri tabanı çalışmasında, 943 gen ve genetik marker tespit edilmiş ve bunlardan 359 adedinin miRNA'lardan etkilendiği ifade edilmiştir (44). Ayrıca miR-21, miR-23a ve miR-24'ün meme dokusunda spesifik olarak ifade edildiği bildirilmektedir (21). İneklerde meme dokusunun durumu yaş, gebelik ve laktasyon dönemleri gibi fizyolojik koşullar altında değişiklik göstermektedir (3). Farklı laktasyon dönemlerinde (Kuru Dönem= Doğumdan önceki 30 gün, Fresh Dönem= Doğumdan sonraki 7 gün, Erken Laktasyon Dönemi= Doğumdan sonraki 8-30 gün) 13 miRNA'nın (miR10a, miR-15b, miR-16, miR-21, miR-31, miR-33b, miR-145, miR-146b, miR-155, miR-181a, miR-205, miR-221 ve miR-223) ekspresyon profilinin incelendiği bir çalışmada, erken laktasyon döneminde miR-31 ekspresyonunun arttığı, fresh dönemde ise diğer miRNA'ların ekspresyonlarının arttığı bildirilmiştir (56). Sığırlarda mastitis vakalarında immun yanıtın şekillenmesinde BOLA-DQA2 (Bovine Leukocyte Antigen-DQ Alpha 2) geninin önemli fonksiyonu bulunmaktadır. Bu geni hedefleyen miR-296, miR-2430 ve miR-67'nın ekspresyonunun normal meme dokusuna göre mastitisten etkilenen meme dokusunda yüksek, miR-2328'in ise düşük seviyede olduğu bildirilmektedir (23). Bu durum, sığırlarda süt verimi ve mastitis üzerinde miRNA'ların etkili olduğunu ortaya çıkarmaktadır.

MiRNA'ların kan ve süt gibi vücut sıvılarında yüksek düzeyde ve stabil olarak bulunmalarından dolayı çeşitli metabolik ve fizyolojik olaylarda potansiyel biyomarker olarak kullanılabileceği bildirilmiştir (18). Sığırlarda laktasyonun farklı dönemlerinde 108 miRNA'nın ekspresyonun incelendiği bir çalışmada, kolostrumda bu miRNA'ların ekspresyon seviyesi yüksek düzeyde bulunmuştur.

Ayrıca, incelenen miRNA'lardan 7'sinin ekspresyon seviyesi tüm laktasyon dönemlerinde benzer bulunmuş olup bunun (Şekil 2) işlenmiş süt ve süt ürünlerinde kalitenin belirlenmesinde kullanılabilecek bir marker olabileceği dile getirilmektedir (8).

\subsection{Küçük ruminantlarda mikroRNA'lar}

Küçük ruminantlarda miRNA'lar ile ilgili çalışmalar yapağı verimi, üreme organlarının gelişimi ve iskelet kası üzerinde yoğunlaşmıştır (59).

Merinos ırkı koyunlar ve Kaşmir keçilerinde 159 miRNA’nın ekspresyonunun incelendiği bir çalışmada, 19 miRNA'nın spesifik olarak vücut derisi (body side skin) ile kulak derisinde (ear skin) eksprese edildiği bildirilmiştir. Bu sonuçlar neticesinde miRNA' ların yapağı ve kıl büyümesi üzerine spesifik etkilerinin olabileceği ortaya konmuştur (58).

Koyunlarda gebeliğin 42. ve 75. günlerinde, fötal gonadlarda, 128 miRN ekpresyonunun incelendiği bir çalışmada (51), testiküler kordonun geliştiği 42. günde 24 miRNA'nın eşeysel dimorfik ekspresyon gösterdiği tespit edilmiştir. Bu miRNA'lardan 12 adedinin ekspresyon seviyesi dişi (XX) gonadlarda, 12 adedinin ise erkek (XY) gonadlarda önemli derecede yüksek bulunmuştur. Primordial foliküllerin geliştiği 75. günde ise 43 miRNA eşeysel dimorfik ekspresyon göstermiş olup bunlardan 26'sının ekspresyon seviyesi ovaryumlarda, 17'sinin ise testislerde yüksek bulunduğu bildirilmiştir. Aynı çalışmada, koyunlarda ovaryum gelişimi üzerine etkili (ESR1, ESR2, CYP19, FST ve WNT4) genler ile testis gelişimi üzerine etkili (SOX9) genlerin gebeliğin 42. ve 75. günlerindeki ekspresyon seviyeleri belirlenmiştir. miR-22'nin hedef geninin ESR-1 olması ve testislerde yüksek düzeyde ekspresyon seviyesi (0.953) göstermesi ile östrojen sinyalizasyonu arasında ilişki bulunmuştur. Bu sonuçlara dayanarak fötal gonadal gelişimin altında yatan gen ekspresyonları üzerinde miRNA'ların etkili olduğu anlaşılmaktadır (51).

Romanov X Texel F2 generasyonu koyunlar üzerinde yapılan bir çalışmada, miR-1 ve miR-206'nın iskelet kasında yüksek düzeyde ifade edildiği ve bu miRNA'ların miyostatin geni üzerinde etkili olarak muskuler hipertrofiye neden olan faktörler arasında yer alabileceği bildirilmiştir (12).

Fransa'da koyunlar üzerinde yapılan bir çalışmada (19), ilkine doğum yapan Prealpes du Sud ırkı koyunlarda, gebeliğin farklı periyotlarında ve laktasyon döneminde çeşitli miRNA'ların ekspresyon profilleri incelenmiştir. Meme epitel hücrelerinde gebeliğin erken döneminde miR-21 ve miR-205, orta döneminde miR-21 ve ileri dönemde ise miR205'in ekspresyonu yüksek bulunmuştur. İleri gebelik dönemi ve laktasyonda miR-200 grubu (miR-200a, miR-200b, 
miR-200c, miR-141, miR-429) miRNA'ların ekspresyon seviyeleri yüksek olmuştur. Sütçü keçiler üzerinde yapılan çalışmalarda (Xinong Saanen Chinese Dairy Goat) laktasyonun farklı dönemlerinde çok sayıda miRNA'nın tespit edildiği bildirilmektedir (18).

\subsection{Atlarda mikroRNA’lar}

Atlarda, kemik ve kıkırdak gelişimi ile glikojen metabolizması üzerine miRNA çalışmaları bulunmaktadır (15, 20).

Taylarda sıklıkla görülen, hayvan refahını olumsuz etkileyen ve ekonomik açıdan da ciddi kayıplarla neticelenen bir bozukluk olan Osteokondrozis (Equine osteochondrosis), etiyolojik ve patojik yönden tam olarak aydınlatılamamış bir hastalıktır. Bu hastalığın oluşumunda etkili olabilecek genetik mekanizmaların araştırıldığı bir çalışmada, epifizyal kıkırdak ve subkondral kemik bölgelerinden elde edilen miRNA'lar sağlıklı ve defektli dokularda farklı ekspresyon seviyeleri göstermiştir. $\mathrm{Bu}$ da, osteokondrozis oluşumunda miRNA'ların rolü olabileceğini düşündürmektedir (15).

Atlarda fiziksel egzersiz, glikojen metabolizmasını etkileyen genlerin (Laktat Dehidrojenaz-LDHA ve Glikojen Sentaz 1-GYS1) ekspresyon seviyelerinde değişikliğe neden olmaktadır (17). Bu gen ekspresyonlarına etki eden faktörlerin araştırıldığı bir çalışmada, eca miR-33a ve miR17'nin LDHA ve GYS1 genlerinin 3' UTR'sine bağlanarak ekspresyonu inhibe ettiği bildirilmektedir (20).

\subsection{Tavuklarda mikroRNA'lar}

Tavuklarda miRNA'lar ile ilgili ilk çalışma 2006 yılında yapılmış ve 25 miRNA belirlenmiştir (62). Tavuklarda bulunan miRNA'ların embriyonik gelişim, iskelet kası ve yağ doku gelişimi üzerine etkili oldukları bildirilmiştir (59).

Tavuklarda gonadal cinsiyet farklılaşmasının değişik aşamalarında, mikroarray yöntemi kullanılarak miRNA ekspresyonlarının araştırıldığı bir çalışmada, erkek ve dişi eşeyler arasında vücut boyutu ve şekli, renk veya desen bakımından farklılıklar görülmesini sağlayan, eşeysel dimorfik bir miRNA olan miR-202* erkek gonadlarda tespit edilmiştir. Sonuçların in situ hibridizasyon ve northern blot yöntemleriyle de doğrulanmış olması bu miRNA'nın erkek gonad gelişiminde rolünün olduğunu göstermektedir $(4,5)$. Tavuklarda eşeysel dimorfik etki oluşturan diğer bir miRNA, miR-363'tür. Tavuk embriyosunda eşey organlarının gelişim aralığı olan 4.5 - 6.5. günler arasında embriyonik gonadlarda miR-363'ün ekspresyon seviyeleri arasındaki farklılık belirlenmiş olup (6.5. günde dişi gonadlarda ekspresyon seviyesi daha yüksek) miR-363'ün tavuklarda erken embriyonik gelişim safhasında gonadlar üzerinde etkili olabileceği bildirilmiştir (24). In situ hibridizasyon yöntemi kullanılarak 135 miRNA profilinin tavuklarda embriyonik gelişim üzerine etkisinin araştırıldığı bir çalışmada ise, bu miRNA'lardan 75 tanesinin değişik dokuların gelişiminde etkili olabileceği ortaya konulmuştur (14). Tavuklarda doğrudan SRY (Sex Determining Region Y) transkripti üzerine bağlanan miR-302a ve miR-456'nın embriyonal dönemde somatik gen ekspresyonu ve farklılaşma üzerine etkili olduğu, mir-181a*'nın ise primordial üreme hücrelerinin farklılaşması üzerinde etkili olduğu bildirilmiştir (33). Ayrıca miR-15c, -29b, -383 ve -222, primordial üreme hücrelerinin oluşumu üzerinde etkili olan DNA metiltransferaz geni DNMT3B (DNA Methyltransferase 3 Beta)'nin ekspresyonunu etkilemektedir (46).

MiR-1a, -133a ve -122'nin kas ve yağ dokularının farklı gelişim aşamasında eksprese olduğu bildirilmektedir. MiR-122 yağ doku ile ilgili iken miRNA-133a ve miR-1a'nın kas doku ile ilişkilidir. Tavuklarda yağ doku ve iskelet kası büyümesi ve gelişmesi için bu miRNA'ların gerekli olduğu, tavuklarda yağ doku ve iskelet kası gelişimi mekanizmasının anlaşılmasında da etkili olabilecekleri bildirilmektedir (57). Başka bir çalışmada ise yumurtacı ve etçi tavuklarda kas oluşumunu etkileyen ACVR2B (Activin Receptor 2B) geninin, miR-1 tarafindan etkilendiği bildirilmektedir (36).

Tavuklarda çok sayıda miRNA'nın kondrogenezde etkili olduğu bildirilmiştir. Mir-221, kıkırdak oluşumu üzerinde etkili MDM2 (Mouse Double Minute 2) genini baskılayarak kıkırdak oluşumunu düzenlemektedir (27). Ayrıca miR-142-3p'nin doğrudan disintegrin ve metalloproteinaz 9 (ADAM 9) geni üzerinden kondrogenezi etkilediği 
bildirilmektedir (29). MiR-365'in primer tavuk kondrositlerinde, kondrosit hipertrofisi inhibitörü olan histon deasetilaz 4 (HDAC4) genini hedefleyerek, kondrosit farklılaşmasını uyarma fonksiyonu olduğu tespit edilmiştir (22), miR34a'nın ise EphA5 (Ephrin Type-A Receptor 5) geninin ekspresyonunu baskılayarak kondrogenezi düzenlediği ortaya konmuştur (28).

İnsanda ise miRNA'lar ile ilgili çalışmalar kanser hastalığının mekanizmasının anlaşılması üzerine yoğunlaşmaktadır. Bu çalışmalara benzer olarak, tavuklarda da miR-206'nın IL-2 (Interleukin 2)'nin ekspresyonunu azaltarak tümör baskılayıcı (kontrolsüz hücre çoğalmasının elgellenmesi) rolü olduğu bildirilmektedir $(4,63)$.

\subsection{Domuzlarda mikroRNA'lar}

Domuzlarda üreme sistemi, iskelet kası, yağ gelişimi ve immun sistem ile ilgili miRNA'lar tanımlanmıştır

Domuzlarda miRNA ekspresyon profillerinin belirlenmesinde mikroarray yöntemi yoğun bir şekilde kullanılmaktadır. Bu yöntemle domuzlarda ve insanlarda daha önceden tespit edilen miRNA'lardan oluşan 332 miRNA profilinin incelendiği bir çalışmada, 201 yeni miRNA'nın barsaklarda ifade potansiyelinin olduğu bildirilmiştir (50). Cinsel olgunluk dönemi öncesi ve sonrasında domuz testislerinde 129 miRNA'nın farklı düzeyde ifade edilmesi domuzlarda miRNA'ların spermatogenez üzerinde etkili olduğunu düşündürmektedir (39). Domuzlarda normal spermalarla karşılaştırıldığında, anormal spermalarda let-7a, let-7d, let-7e ve miR-22'nin ekspresyon seviyesi yüksek, miR-15b'nin ekspresyon seviyesi düşük bulunmuştur. Dolayısıyla, bu miRNA'ların sperm gelişimi üzerinde etkili olabilecekleri düşünülmektedir (13).

Minyatür domuzlar (Sus scrofa), obezitenin mekanizmasının araştırılmasında model olarak kullanılan önemli bir deney hayvanıdır. MiR-122'nin lipid metabolizması üzerinde önemli etkileri bulunmaktadır. İnsanlarda günlük diyetle yüksek yağ alımının obezite üzerine etkisinin incelenmesi amacıyla minyatür domuzlar üzerinde yapılan bir çalışmada, erkek minyatür domuzlar 11 hafta yüksek ve standart düzeyde kolesterol içeren rasyonlarla beslenmişlerdir. Yüksek kolesterollü rasyon ile beslenen grubun vücut ağırlığı, toplam kolesterol ve HDL (High Density Lipoprotein) değerleri yüksek bulunmuş olup miRNA-122 ekspresyon seviyesinin düşük olması ile aralarında korelasyon olduğu bildirilmiştir. (10). Çin'de yetiştirilen ve yağlı bir domuz ırkı olarak bilinen Meishan domuzları ile bu ırka göre nispeten daha az yağlı olan Beyaz (Large White) domuzlarda çesitli miRNA'lara ait ekspresyon profillerinin incelendiği diğer bir çalışmada, Beyaz domuzlarda miR-215, -135, -224 ve -146b'nin ekspresyon seviyesi yüksek; miR-1a, -133a, -122, -204 ve -183'ün ekspresyon seviyesi düşük bulunmuştur (9). Ekspresyon seviyeleri arasındaki bu farklılık, domuzlarda miRNA'ların büyüme ve yağ dokusu oluşumu üzerine etkili olabileceklerini düşündürmektedir (59).

Domuzlarda miRNA'ların fonksiyonel etkileri ile hedef genlerinin belirlendiği çalışmalar da bulunmaktadır. MiR-148b, domuz yavrularında yayvan bacaklılık hastalığı ile ilişkili olan ITGA5 (Integrin Alpha 5) genini hedeflemektedir (40). Beyaz domuzlar ile Çin'de geliştirilen ve yağsız bir domuz hattı olan DIV (Dam line of Chinese lean-type pigs) domuzlarında mir-27a genindeki bir T/C SNP (Single nucleotide polymorphism)'in yavru verimini etkilediği bildirilmektedir (34). MiR-378, ovaryum granulosa hücrelerini etkileyerek östradiol üretimi ve androjenlerin östrojenlere dönüştürülmesinden sorumlu bir enzim olan aromataz aktivitesini azaltmakta ve foliküler gelişim üzerinde etkili olmaktadır (64). MiR-155, iskelet kası gelişiminde etkili olan OLFML3 (Olfactomedin like 3) geninin ekspresyonunu etkilemektedir (66). Domuzlarda yağ doku ve dalakta yüksek düzeyde ekspresyon seviyesine sahip olan miR-155, organizmaya giren patojenlerin fark edilerek immun yanıtın başlamasını sağlayan TLR (Toll-like receptor) reseptörlerinden TLR3 ve TLR4 sinyalinin gönderilmesini sağlamaktadır. Bu sayede domuzlarda miRNA'ların immun sistem üzerinde etkili olabilecekleri ortaya konulmuştur (37).

\section{Sonuç}

Çiftlik hayvanlarında ekonomik yönden önemli verim özellikleri çok sayıda faktörün etkisi altında olup kantitatif niteliktedir. Sığır, koyun, keçi, at, tavuk ve domuzlarda miRNA'lar ile ilgili yapılan çalışmalar, bu moleküllerin ekonomik yönden önemli verim özellikleri üzerinde etkili olduklarını göstermektedir. Ancak 
miRNA'ların seleksiyon programlarına girerek yetiştiricilikte uygulama alanı bulabilmesi için, bu moleküllerin hedef genleri ve verim özellikleri arasındaki ilişkilerin daha somut bir şekilde ortaya konulması gerekmektedir. Aksi takdirde hali hazırda yüzlerce bilinmeyeni olan bir denkleme bir bilinmeyen daha eklenmiş olacaktır. Dolayısıyla çiftlik hayvanlarında miRNA'ların kullanım alanlarına ilişkin daha fazla araştırma yapılmasına ve böylelikle konunun açıklığa kavuşturulmasına ihtiyaç duyulmaktadır.

\section{Kaynaklar}

1. Abd EI Naby WS, Hagos TH, Hossain MM, Salilew-Wondim D, Gad AY, Rings F, Cinar MU, Tholen E, Looft C, Schellander K, Hoelker M, Tesfaye D (2011): Expression analysis of regulatory microRNAs in bovine cumulus oocyte complex and preimplantation embryos. Zygote, 11, 1-21.

2. Akçapınar H, Özbeyaz C (1999). Hayvan Yetiştiriciliği Temel Bilgiler 1. Bask1, Kariyer Matbaacılık. ISBN: 97596978-0-7. Ankara.

3. Annen E, Stiening C, Crooker B, Fitzgerald A, Collier R (2008): Effect of continuous milking and prostaglandin E2 on milk production and mammary epithelial cell turnover, ultrastructure, and gene expression. J Anim Sci, 86, $1132-1144$.

4. Anonim (2014). Vikipedi. Erişim Adresi: http://en.wikipedia.org Erişim Tarihi: 21.08.2014

5. Bannister SC, Tizard ML, Doran TJ, Sinclair AH, Smith CA (2009): Sexually dimorphic microRNA expression during chicken embryonic gonadal development. Biology of Reproduction, 81, 165-176.

6. Bartel DP (2004). MicroRNAs: genomics, biogenesis, mechanism, and function. Cell, 116: 281-297.

7. Berry C, Thomas M, Langley B, Sharma M, Kambadur R (2002). Single cysteine to tyrosine transition inactivates the growth inhibitory function of Piedmontese myostatin. American Journal of Physiology Cell Physiology, 283: $135-141$.

8. Chen X, Gao C, Li H, Huang L, Sun Q, Dong Y, Tian C, Gao S, Dong H, Guan D, Hu X, Zhao S, Li L, Zhu L, Yan Q, Zhang J, Zen K, Zhang CY (2010): Identification and characterization of microRNAs in raw milk during different periods of lactation, commercial fluid, and powdered milk products. Cell Res, 20, 1128-1137.

9. Chen C, Deng B, Qiao M, Zheng R, Chai J, Ding Y, Peng J, Jiang S (2012). Solexa sequencing identification of conserved and novel microRNAs in backfat of Large White and Chinese Meishan pigs. PLoS One, 7: e31426.

10. Cirera S, Birck M, Busk PK, Fredholm M (2010): Expression profiles of miRNA-122 and its target CAT1 in minipigs (Sus scrofa) fed a high-cholesterol diet. Comparative Medicine, 60, 136-141.

11. Clancy S (2008): RNA functions. Nature Education, 1 (1),1047.

12. Clop A, Marcq F, Takeda H, Pirottin D, Tordoir X, Bibe B, Bouix J, Caiment F, Elsen JM, Eychenne F, Larzul C, Laville E, Meish F, Milenkovic D, Tobin J, Charlier C, Georges M (2006): A mutation creating a potential illegitimate microRNA target site in the myostatin gene affects muscularity in sheep. Nature Genetics, 38, 813-818.

13. Curry E, Safranski TJ, Pratt SL (2011): Differential expression of porcine sperm microRNAs and their association with sperm morphology and motility. Theriogenology, 7, 1532-1539.

14. Darnell DK, Kaur S, Stanislaw S, Konieczka JH, Yatskievych TA, Antin PB (2006): MicroRNA expression during chick embryo development. Developmental Dynamics, 235, 3156-3165.

15. Desjardin C, Vaiman A, Mata Legendre R, Laubier J, Kennedy SP, Laloe D, Barrey D, Jacques C, Cribiu EP, Schibler L (2014): Next-generation sequencing identifies equine cartilage and subchondral bone miRNAs and suggests their involvement in osteochondrosis physiopathology. BMC Genomics, 15, 798.

16. Di Leva G, Calin GA, Croce CM (2006) MicroRNAs: fundamental facts and involvement in human diseases. Birth Defects Res C Embryo Today, 78(2), 180-9.

17. Eivers SS, Mcgivney BA, Fonseca RG, Machugh DE, Menson K, Park SD, Rivero JL, Taylor CT, Katz LM, Hill EW (2010). Alterations in oxidative gene expression in equine skeletal muscle following exercise and training. Physiol. Genomics, 40, 83-93.

18. Fatima A, Morris DG (2013). MicroRNAs in domestic livestock. Physiol. Genomics, 45, 685-696. 
19. Galio L, Droineau S, Yeboah P, Boudiaf H, Bouet S, Truchet S, Devinoy E. (2013). MicroRNA in the ovine mammary gland during early pregnancy: spatial and temporal expression of miR-21, miR-205, and miR-200. Physiol Genomics, 45, 151-161.

20. Gima JA, Ayarpadikannana S, Eoa J, Kwona Yj, Choia Y, Leeb, HY, Parkb KD, Yangc YM, Chod BW, Kima HS (2014). Transcriptional expression changes of glucose metabolism genes after exercise in thoroughbred horses. Gene, 547, 152-158.

21. Gu Z, Eleswarapu S, Jiang $\mathbf{H}$ (2007). Identification and characterization of microRNAs from the bovine adipose tissue and mammary gland. FEBS Lett, 581, 981-988.

22. Guan YJ, Yang X, Wei L, Chen Q (2011). MiR-365: a mechanosensitive microRNA stimulates chondrocyte differentiation through targeting histone deacetylase 4. FASEB Journal, 25, 4457-4466.

23. Hou Q, Huang J, Ju Z, Li Q, Li L, Wang C, Sun T, Wang L, Hou M, Hang S, Zhong J (2011): Identification of splice variants, targeted microRNAs and functional single nucleotide polymorphisms of the BOLA-DQA2 gene in dairy cattle. DNA Cell Biol, 15, 15.

24. Huang P, Gong Y, Peng X, Li S, Yang Y, Feng Y (2010): Cloning, identification, and expression analysis at the stage of gonadal sex differentiation of chicken miR-363 and 363*. Acta Biochimica et Biophysica Sinica, 42, 522-529. 25. Jevsinek Skok, D, Godnic, İ, Zorc M, Horvat S, Dovc,P, Kovac M, Kunej T. (2013). Genome-wide in silico screening for microRNA genetic variability in livestock species. Animal Genetics Volume 44 (6): 669-677.

26. Jin W, Dodson MV, Moore SS, Basarab JA, Guan LL (2010): Characterization of microRNA expression in bovine adipose tissues: a potential regulatory mechanism of subcutaneous adipose tissue development. BMC Molecular Biology, 11, 29.

27. Kim D, Song J, Jin EJ (2010): MicroRNA-221 regulates chondrogenic differentiation through promoting proteosomal degradation of slug by targeting Mdm2. Journal of Biological Chemistry, 285, 26900-26907.

28. Kim D, Song J, Kim S, Chun CH, Jin EJ (2011a): MicroRNA-34a regulates migration of chondroblast and IL1beta-induced degeneration of chondrocytes by targeting EphA5. Biochemical and Biophysical Research Communications, 415, 551-557.

29. Kim D, Song J, Kim S, Kang SS, Jin EJ (2011b): MicroRNA-142-3p regulates TGF-beta3-mediated regiondependent chondrogenesis by regulating ADAM9. Biochemical and Biophysical Research Communications, 414, 653659.

30. Küçükhüseyin Ö, Öztürk O (2013): miRNA 'lar ve Meme Kanserindeki Etkileri. Deneysel Tıp Araştırma Enstitüsü Dergisi, 3(5), 13-24.

31. Lagos-Quintana M, Rauhut R, Lendeckel W, Tuschl T (2001): Identification of novel genes coding for small expressed RNAs. Science, 294, 853-858.

32. Lee RC, Feinbaum RL, Ambros V (1993): The C. elegans heterochronic gene lin-4 encodes small RNAs with antisense complementarity to lin-14, Cell, 75, 843-854.

33. Lee SI, Lee BR, Hwang YS, Lee HC, Rengaraj D, Song G, Park TS, Han JY (2011): MicroRNA-mediated posttranscriptional regulation is required for maintaining undifferentiated properties of blastoderm and primordial germ cells in chickens. Proceedings of the National Academy of Sciences of the United States of America, 108: 1042610431.

34. Lei B, Gao S, Luo LF, Xia XY, Jiang SW, Deng CY, Xiong YZ, Li FE (2011): A SNP in the miR-27a gene is associated with litter size in pigs. Molecular Biology Reports, 38, 3725-3729.

35. Li H, Zhang Z, Zhou X, Wang Z, Wang G, Han Z (2011a): Effects of microRNA-143 in the differentiation and proliferation of bovine intramuscular preadipocytes. Molecular Biology Reports, 38, 4273-4280.

36. Li T, Wu R, Zhang Y, Zhu D (2011b): A systematic analysis of the skeletal muscle miRNA transcriptome of chicken varieties with divergent skeletal muscle growth identifies novel miRNAs and differentially expressed miRNAs. BMC Genomics, 12, 186.

37. Li C, He H, Zhu M, Zhao S, Li X (2013): Molecular characterisation of porcine miR-155 and its regulatory roles in the TLR3/TLR4 pathways. Developmental and Comparative Immunology, 39, 110-116.

38. Lingenfelter BM, Tripurani SK, Tejomurtula J, Smith GW, Yao J (2011): Molecular cloning and expression 
of bovine nucleoplasmin 2 (NPM2): a maternal effect gene regulated by miR-181a. Reproductive Biology and Endocrinology, 9, 40.

39. Luo L, Ye L, Liu G, Shao G, Zheng R, Ren Z, Zuo B, Xu D, Lei M, Jiang S, Deng C, Xiong Y, Li F (2010): Microarray-based approach identifies differentially expressed microRNAs in porcine sexually immature and mature testes. PLoS One, 5, e11744

40. Maak S, Boettcher D, Komolka K, Tetens J, Wimmers K, Reinsch N, Swalve HH, Thaller G (2010): Exclusion of sequence polymorphisms in the porcine ITGA5 and MIR148B loci as causal variation for congenital splay leg in piglets. Animal Genetics, 41, 447-448.

41. Miles JR, Mcdaneld TG, Wiedmann RT, Cushman RA, Echternkamp SE, Vallet JL, Smith TP (2012): MicroRNA expression profile in bovine cumulus-oocyte complexes: possible role of let-7 and miR-106a in the development of bovine oocytes. Animal Reproduction Science, 130, 16-26.

42. Mondou E, Dufort I, Gohin M, Fournier E, Sirard MA (2012): Analysis of microRNAs and their precursors in bovine early embryonic development. Molecular Human Reproduction, 18, 425-434.

43. Naguibneva I, Ameyar-Zazoua M, Polesskaya A, Ait-Si-Ali S, Groisman R, Souidi M, Cuvellier S, HarelBellan A (2006): The microRNA miR-181 targets the homeobox protein Hox-A11 during mammalian myoblast differentiation. Nature Cell Biology, 8, 278-284.

44. Ogorevc J, Kunej T, Razpet A, Dove P (2009): Database of cattle candidate genes and genetic markers for milk production and mastitis. Anim Genet, 40, 832-851.

45. Reinhart BJ, Slack FJ, Basson, M, Pasquinelli AE, Bettinger JC, Rougvie AE, Ruvkun G (2000): The 21nucleotide let-7 RNA regulates developmental timing in Caenorhabdi $\neg$ tis elegans. Nature, 403, 901-906.

46. Rengaraj D, Lee BR, Lee SI, Seo Hw, Han JY (2011): Expression patterns and miRNA regulation of DNA methyltransferases in chicken primordial germ cells. PLoS One, 6, e19524.

47. Ribas L, Pardo BG, Fernandez C, Alvarez-Dios JA, Gomez-Tato A, Quiroga MI, Planas JV, Sitja-Bobadilla A, Martinez P, Piferrer F (2013): A combined strategy involving Sanger and 454 pyrosequencing increases genomic resources to aid in the management of reproduction, disease control and genetic selection in the turbot (Scophthalmus maximus). BMC GENOMICS, 14, 180.

48. Romao JM, Jin W, He M, Mcallister T, Guan LL (2012): Altered microRNA expression in bovine subcutaneous and visceral adipose tissues from cattle under different diet. PLoS One 7: e40605.

49. Saydam F, Değirmenci İ, Güneş HV (2011): MiRNA'lar ve kanser. Dicle Tıp Dergisi, 38 (1), 113-120.

50. Sharbati S, Friedlander Mr, Sharbati J, Hoeke L, Chen W, Keller A, Stahler Pf, Rajewsky N, Einspanier R (2010). Deciphering the porcine intestinal microRNA transcriptome. BMC Genomics, 11: 275.

51. Torley KJ, Da Silveira JC, Smith P, Anthony RV, Veeramachaneni DN, Winger QA, Bouma GJ (2011): Expression of miRNAs in ovine fetal gonads: potential role in gonadal differentiation. Reproductive Biology and Endocrinology, 9, 2.

52. Townley-Tilson WH, Callis TE, Wang D (2010): MicroRNAs 1, 133, and 206: critical factors of skeletal and cardiac muscle development, function, and disease. The International Journal of Biochemistry \& Cell Biology, 42, $1252-1255$.

53. Tripurani SK, Lee KB, Wee G, Smith GW, Yao J (2011): MicroRNA-196a regulates bovine newborn ovary homeobox gene (NOBOX) expression during early embryogenesis. BMC Developmental Biology, 11, 25.

54. Tunalı NE, Tiryakioğlu NO (2010): Kanserde MiRNA'ların Rolü Türkiye Klinikleri J Med Sci, 30 (5): 1690-700. 55. Van Rooij $\boldsymbol{E}$ (2011). The art of microRNA research. Circ Res, 108 (2), 219-234.

56. Wang M, Moisa S, Khan MJ, Wang J, Bu D, Loor JJ (2012a): MicroRNA expression patterns in the bovine mammary gland are affected by stage of lactation. J Dairy Sci, 6, 6 .

57. Wang XG, Yu JF, Zhang Y, Gong DQ, Gu ZL (2012b): Identification and characterization of microRNA from chicken adipose tissue and skeletal muscle. Poultry Science, 91, 139-149.

58. Wang X, Gua Z, Jianga $\mathbf{H}$ (2013). MicroRNAs in farm animals. Animal, 7, 1567-1575.

59. Wenguang Z, Jianghong W, Jinquan L, Yashizawa M (2007): A subset of skinexpressed microRNAs with possible roles in goat and sheep hair growth based on expression profiling of mammalian microRNAs. OMICS, 11: 
385-396.

60.Wightman B, Ha I, Ruvkun G (1993): Posttranscriptional regulation of the heterochronic gene lin-14 by lin-4 mediates temporal pattern formation in C. elegans. Cell, 75 (5), 855-862.

61. Wijnhoven BP, Michael MZ, Watson DI (2007). MicroRNAs and cancer. Br J Surg, 94, 23-30.

62. Xu H, Wang X, Du Z, Li N (2006): Identification of microRNAs from different tissues of chicken embryo and adult chicken. FEBS Letters, 580, 3610-3616.

63. Xu H, Yao Y, Smith LP, Nair V (2010): MicroRNA-26a-mediated regulation of interleukin-2 expression in transformed avian lymphocyte lines. Cancer Cell International, 10, 15.

64. Xu S, Linher-Melville K, Yang BB, Wu D, Li J (2011): Micro-RNA378 (miR-378) regulates ovarian estradiol production by targeting aromatase. Endocrinology, 152, 3941-3951.

65. Zhao C, Tian F, Yu Y, Liu G, Zan L, Updike MS, Song J (2012a). miRNA dysregulation associated with tenderness variation induced by acute stress in Angus cattle. Journal of Animal Science and Biotechnology, 3, 12.

66. Zhao S, Zhang J, Hou X, Zan L, Wang N, Tang Z, Li K (2012b): OLFML3 expression is decreased during prenatal muscle development and regulated by microRNA-155 in pigs. International Journal of Biological Sciences, $\mathbf{8}$, 459-469. 